\title{
TEST PRO IDENTIFIKACI NADANÝCH ŽÁKŮ V MATEMATICE Recenze metody
}

\author{
AUTORKA RECENZE: LENKA KREJČOVÁ ${ }^{1}$
}

\begin{tabular}{|l|l|}
\hline Účel: & $\begin{array}{l}\text { M̌̌ření matematického usuzování v pásmu nadprůměru u žáků } \\
\text { ZS }\end{array}$ \\
\hline Populace: & Žáci 3. až 5. ročníkủ ZŠ \\
\hline Rok vydání: & 2017 \\
\hline Zkratka metody: & TIM$^{3-5}$ \\
\hline Škály: & Celková škála ve formátu HS, percentilu, T-skóru, W-skóru a RPI-1 \\
\hline Administrace: & Skupinová i individuální, tužka-papír \\
\hline Formy: & Dvě plně paralelní formy \\
\hline $\begin{array}{l}\text { Čas } \\
\text { administrace: }\end{array}$ & 45 minut \\
\hline Autoři: & Hynek Cígler, Michal Jabůrek, Ondřej Straka, Šárka Portešová \\
\hline Vydavatel: & Masarykova Univerzita \\
\hline
\end{tabular}

Test pro identifikaci nadaných žáků v matematice pro 3. - 5. třídu (dále TIM3-5) je v souladu se svým názvem určen pro zmapování matematického nadání žáků prvního stupně základní škol, konkrétně ve 3. - 5. ročníku. Primárně vznikl pro děti, u nichž je nadání předpokládáno, nikoli pro celkovou populaci žáků v uvedeném věku.

Je administrován metodou „tužka - papír“, lze ho využít k individuální i skupinové diagnostice. Pro účely skupinové diagnostiky, resp. rediagnostiky jedince, byly vytvořeny dvě paralelní verze. Test obsahuje 25 položek, jež mají všechny charakter početní operace. $V$ závislosti na způsobu řešení úlohy jsou některé skórovány 0 či 1 (správná versus nesprávná odpověd'), jiné 0,1 či 2 body (1 bod značí odpověd', která není zcela přesná, avšak svědčí pro matematické uvažování a adekvátní postup řešení, ale s určitými nedostatky či nepřesnostmi).

Vyhodnocení výsledků je možné provést manuálně, nebo za využití online aplikace. Hrubý skór, jenž je prostým součtem bodů za správně řešené položky, je převáděn na percentily, T-skóry, W-skóry a RPI-1 index. Výsledky probanda jsou tak porovnávány jak s jeho vrstevnickou skupinou, tak v rámci jeho vlastního individuálního profilu. U každé položky online aplikace dále vygeneruje pravděpodobnost správné či chybné odpovědi u

\footnotetext{
${ }^{1}$ Katedra psychologie, Filozofická fakulta UK, nám. Jana Palacha 2, 11638 Praha 1
} 
konkrétního jedince a současně vyznačí takové položky, které jsou v kontextu dalších řešených úloh zodpovězeny nečekaným způsobem.

Uživatel má k dispozici Testovací sešity, Vyhodnocovací listy, Uživatelskou příručku, Psychometrický manuál a vstup do online aplikace, v níž jsou veškeré uvedené materiály rovněž ke stažení, a především zde probíhá evidence a zpracování výsledků jednotlivých probandů. Každý uživatel má vytvořen individuální účet, takže může mít data svých probandů kdykoliv k dispozici online, nebo exportovaná ve formátu PDF.

Ve školním roce 2015/2016 se shodou okolností Česká školní inspekce detailněji zabývala prací škol se žáky, kteří vykazují nadání v určité vzdělávací oblasti. Ze zjištění vyplynulo, že školy nadání žáků mnohdy přehlížejí, řada škol nevyužívá žádné specifické postupy práce, jež by vedly $\mathrm{k}$ rozvoji nadaných žáků a podpoře jejich potenciálu. I zkušenosti z praxe často ukazují, že nadaní žáci jsou ve škole často vnímáni jako ti, kterým se učení příslušného vyučovacího předmětu jednoduše daří dobře, $\mathrm{v}$ horších, ovšem nikoli výjimečných případech, jsou chápáni jako žáci problematičtí, protože jim nestačí standardní výuka, někdy dokonce tuto výuku narušují svými dotazy a požadavky. Mají-li žáci nadání pro určitou oblast, očekává se, že ho budou rozvíjet formou volnočasových, mimoškolních aktivit, a to dokonce i tehdy, když se jedná o sféru ve výuce běžně zastoupenou tradičními vyučovacími předměty. Právě proto je oceněníhodné, že si autoři metody TIM3-5 zvolili téma matematického nadání a vytvořili nástroj, jenž umožňuje jeho detailnější prozkoumání. Za pozornost stojí také fakt, že se jedná o jeden z mála diagnostických nástrojů, jež se zaměřují na potenciál jedince, nikoli na jeho deficity.

TIM3-5 byl vyvíjen s maximální důsledností a důkladností. Počáteční koncepce testu je v Uživatelském manuálu popsána velmi zevrubně. Pozornost je věnována klíčovým teoriím matematického nadání, jež jsou vzájemně konfrontovány a kriticky hodnoceny. Mnohdy se ukazuje, že velmi podrobné teorie a př́istupy nemají oporu v obsáhlejších výzkumech, což autoři komentují a dávají do souvislostí s východisky své metody. Na závěr si stanovují klíčové oblasti, v nichž lze matematické nadání sledovat, mezi něž patří schopnost rychle a přesně proniknout do podstaty matematického problémů, efektivně matematické úlohy řešit (s minimálním množstvím početních úkonů), zobecňovat matematické obsahy, flexibilně uvažovat o možnostech řešení, specifické zaměřené paměti a schopnost účinně uchovávat a vybavovat matematicky relevantní obsahy i zaměření mysli na matematiku. Pro účely diagnostického nástroje, při jehož použití nelze spolehlivě diagnostikovat všechny uvedené schopnosti, byly z výčtu vybrány schopnost náležitě uchopit matematickou podstatu problému, flexibilita myšlení při řešení matematických problémů a zčásti také schopnost zobecňovat matematické obsahy.

Za pozornost také stojí, že test umožňuje zvažovat možnosti, jak mohou žáci úlohy řešit. Hodnocení není postaveno pouze na výsledcích výpočtů, ale sleduje postupy, dokonce specificky skóruje běžné chybné odpovědi, jež svědčí pro matematické uvažování na vyspělejší úrovni a spíše jsou způsobeny nepřesností ve výpočtu. Hodnocení nestaví jen na tom, co je zjevné (zapsaný výsledek), ale zvažuje způsoby přemýšlení probandů, jejich flexibilitu, dokonce odlišuje způsoby možných řešení, resp. odpovědí, jež lze očekávat od žáků, kteří matematiku dobře ovládají, avšak spíše neprojevují specifické nadání pro tuto oblast. V této souvislosti je oceněníhodné také citlivé zvažování cílové skupiny žáků, pro něž lze test využít. Administrátoři metody jsou rozhodně zrazováni od jejího plošného použití, zejména pak v nižších věkových skupinách, což by vedlo k demotivaci žáků a jejich negativnímu hodnocení, pokud by jejich matematické dovednosti nebyly vysloveně nadprůměrné. 
Komplexní zpracování veškerých získaných dat, za využití Raschova modelu, je obdivuhodné. Informace jsou prezentovány velmi detailně, všechny postupy jsou zdůvodňovány a precizně popisovány. Je zjevné, že se na standardizaci podíleli autoři s excelentní psychometrickou erudicí. Prostřednictvím Raschova modelu jsou v rámci standardizace zvažovány dílčí položky testu, nikoli prosté součty a průměry hrůbých skórů, resp. rozptyly. Díky užití tohoto modelu je mezi výstupy testu zařazen i W-skór, potažmo index relativní zběhlosti (RTI), což umožňuje komplexnější analýzu výsledků, včetně odhadů schopností a výkonosti sledovaných žáků v edukačním procesu. Testretestová reliabilita (druhé testování proběhlo po 3-4 měsících od prvního testování, a to za užití paralelní formy testu) a reliabilita paralelních forem (Pearsonova korelace paralelních forem $\mathrm{v}$ uvedeném časovém odstupu byla pro jednotlivé postupové ročníky ZŠ v rozmezí 0,682 - 0,793, veškeré výsledky se ukázaly signifikantní na $p<0,0001$ ) byly ověřovány již $\mathrm{v}$ průběhu pilotní studie, nebot' při standardizaci proběhl sběr dat jednorázově. Porovnání výstupů z pilotní a standardizační studie však ukazuje adekvátnost volby tohoto postupu. Autoři porovnávali odhady obtížnosti položek ve verzi určené k pilotní studii s verzí použitou při standardizaci (korelace obtížnosti položek $\mathrm{v}$ obou paralelních formách přesahovala $\mathrm{r}=0,95$ ). Přesto se navíc detailně věnovali obtížnosti jednotlivých položek a v obou paralelních formách, v pilotní a standardizační fázi testu, identifikovali konkrétní položky, jež vykazovaly odlišné hodnoty. Jako příčina se ukázalo pořadí, $v$ němž byly položky v jednotlivých sadách úloh zařazeny. Při zvážení této proměnné se většina položek se všech fází sběru dat již jevila vzájemně srovnatelných. Další analýzy (DIF analýza, t-testy) autoři provedli ještě po sloučení dat z pilotní i standardizační studie. I v tomto případě se rozdíly mezi různými verzemi testů, resp. fázemi sběru dat ukázaly zanedbatelné, proto bylo možné výstupy studií sloučit.

Výsledky analýz ukazují, že test lze spolehlivě použít především u žáků, jejichž matematické dovednosti se jeví skutečně nadprůměrné. To je dáno především faktem, že test je primárně zamýšlet pro zmapování specifického souboru matematických schopností, jež lze pozorovat u žáků s nadáním pro matematiku. Zařazené úlohy jsou proto a priori náročnější, než je běžný standard úloh, jež žáci v příslušném věku zvládají řešit. Tímto je zajištěno, aby se při testování opakovaně neobjevoval tzv. efekt stropu. Na druhou stranu, pokud by byl test užit u žáků s běžnými, nebo dokonce nižším matematickými dovednostmi, opakovaně by se ukazoval tzv. efekt podlahy. Nástroj by takové žáky nediferencoval, tedy ani neposkytoval diagnosticky cenná data.

Pro účely prověření validity metody (primárně byla prověřována kriteriální a konstruktová validita) museli autoři využít diagnostické údaje z komplexních baterií rozumových schopností a některých testů zaměřených na dílčí schopnosti, nebot' v našich podmínkách neexistuje žádný obdobný nástroj. Výsledky dále porovnávali také se školní úspěšností i hodnocením vyučujících, jež mohou posoudit matematické nadání svých žáků. Mimo to sledovali výkony skupiny dětí, jež navštěvovaly specializovaný matematický kurz. Všechny uvedené postupy potvrdily validitu metody.

Výsledky TIM ${ }^{3-5}$ byly porovnávány s výsledky testů rozumových schopností (WJ IE II a WISC-III) administrovaných vybraným probandům $\mathrm{v}$ pedagogicko-psychologických poradnách, později pak cíleně př́mo členy standardizačního týmu. Tam, kde výsledky uvedených metod konstatovaly vyšší nadání jedince, se toto potvrzovalo i výsledky posuzovaného diagnostického nástroje, a to na statisticky významné úrovni. Podobná souvislost byla zjištěna i mezi výsledky TIM $^{3-5}$ a hodnocením učitele, resp. školním prospěchem, či mezi schopností koncentrace pozornosti. V souladu s teorií matematického nadání, jak je pojata $\mathrm{v}$ manuálu TIM $^{3-5}$, se neukázala jednoznačná souvislost mezi matematickým nadáním a prostými numerickými dovednostmi, které 
patrně spíše odrážejí dovednost zapamatování přesných postupů práce i přiměřené pracovní tempo, především na úrovni nižších ročníků ZŠ.

Konstruktová validita testu byla prověřována prostřednictvím sledování rozložení výsledků testu $\mathrm{v}$ populaci, byl zjišt'ován efekt rozvojového programu matematických schopností, který někteří probandi absolvovali, a kde byli někteří přímo lektory označeni jako matematicky významně zdatní. Všechny tyto proměnné potvrdily validitu metody. V neposlední řadě byla zjišt'ována invariance testu prostřednictvím analýzy diferenciálního fungování položek (DIF). Bylo konstatováno, že diagnostický nástroj měří shodně obě pohaví, např́íc postupovými ročníky základní školy, pro něž je určený, tedy i z hlediska věku, i bez ohledu na navštěvovaný typ školy. Zajímavé výsledky přineslo srovnání výkonů žáků se stanoveným matematickým nadáním, žáků s průměrnými výsledky, a naopak žáků s podprůměrnými výkony v testu. Výsledky naznačují, že ve skupině matematicky nadaných žáků TIM ${ }^{3-5}$ měří do jisté míry odlišný konstrukt než v ostatních sledovaných skupinách. Autoři se však rozhodli, že odlišnosti jsou natolik zanedbatelné, že nemají dopad na interpretace výsledků a stávající model testu neměnili.

Pro tvorbu norem byl využit soubor bezmála osmi set probandů z různých krajů České republiky, ze všech tří postupových ročníků základní školy, pro něž je metoda určena, tedy s maximální snahou o reprezentativnost cílové skupiny, pro niž jsou normy určeny. $\mathrm{V}$ různých časech byly administrovány obě paralelní formy testu. Veškerá získaná data byla detailně analyzována, aby bylo prověřeno, že normy v obou formách a pro všechny věkové kategorie uvádějí adekvátní údaje, což bylo potvrzeno. Na základě konfirmační faktorové analýzy pilotní i standardizační verze testu, stejně tak na podkladě výsledků IRT analýzy, zvlášt' pro paralelní formu A a B testu, byl diagnostický nástroj charakterizován jako striktně jednodimenzionální.

Jistým nedostatkem testu je snad jen jeho zaměření na poměrně úzce vymezenou cílovou skupinu. Podobný diagnostický nástroj by bezpochyby našel uplatnění i v jiných věkových kategoriích. Do budoucna by pak stálo za výzkumnou studii, zda je využití TIM³${ }^{5}$ shodné také mezi skupinami žákủ, kteří absolvují tradiční výuku matematiky, a žáky vyučovanými př́stupy, jež se snaží postupovat v souladu s principy konstruktivismu ve výuce.

Blahopřeji autorům k vytvoření jedinečného a užitečného diagnostického nástroje a vřele doporučuji, aby vynaložili dostatečné úsilí pro jeho šíření do výzkumu i praxe. Jinými slovy, Metoda TIM ${ }^{3-5}$ je využitelná v praxi i pro výzkumné účely. Po absolvování adekvátního tréninku ji mohou využívat i učitelé základních škol, kteří s nadanými žáky pracují. Určena je pochopitelně i pro pracovníky školských poradenských zařízení. 


\title{
MODEL RECENZE PODLE EFPA PRO POPIS \\ A HODNOCENÍ PSYCHOLOGICKÝCH TESTŮ \\ FORMULÁŘ RECENZE TESTU A POZNÁMKY PRO \\ RECENZENTY ${ }^{1}$
}

\author{
Toto je lokální úprava dokumentu pro účely publikace v časopise Testfórum. \\ Originální český překlad je k dispozici na stránkách EFPA \\ (www.efpa.eu/download/505cd9db4144ecb16174087909c9cd6d).
}

Od uživatelů tohoto dokumentu a jeho obsahu žádá EFPA, aby uznali tento zdroj prostřednictvím následujícího textu:

"Kritéria pro recenzi testu podle EFPA do značné míry vychází z formy a obsahu kritérií pro recenze testů Britské psychologické společnosti (BPS) a kritérií vytvořených Komisí pro testové záležitosti (COTAN) Holandské asociace psychologů (NIP). Dave Bartram a Patricia Lindley původně vyvinuli kritéria BPS a recenzní procedury pro UK Employment Service a později rozšírili jejich používání pro celou BPS. Arne Evers připravil k vydání nizozemský system posuzování kvality testů.

EFPA je vděčná BPS a NIP za svolení použít jejich kritéria jako základ pro vytvoření evropského modelu. EFPA je také vděčná Davu Bartramovi, Arnu Eversovi a Patricii Lindley za jejich přispění $k$ vývoji tohoto modelu. Veškerá intelektuální vlastnická práva původních kritérií podle BPS a NIP jsou nadále uznávána a náleží těmto orgánům."

\footnotetext{
1 Tento dokument byl vytvořen z několika zdrojů, včetně Hodnotícího formuláře pro recenzi testu používaného v BPS (NPAL a Řídící komise pro testové standardy při BPS - Steering Committee on Test Standards), Španělského dotazníku pro hodnocení psychometrických testů (Španělská psychologická asociace) a Systému pro posuzování kvality testu (Komise pro testování Holandské asociace psychologů). Některé části byly adaptovány se svolením z dokumentu: BPS Books Reviews of Level B Assessment Instruments for use in Occupational Assessment, Notes for Reviewers: Version 3.1. December 1998: Copyright (C) NPAL, 1989, 1993, 1998.

2 Současná verze je spojením dvou oddělených dokumentů (Formuláře recenze a Poznámek pro recenzenty). Obsah byl navíc uspořádán a doplněn na základě jeho používání recenzenty online testů v BPS.
} 


\section{Č́st 1:}

\section{Popis nástroje: Obecné informace a klasifikace}

\begin{tabular}{|c|c|c|}
\hline \multicolumn{3}{|c|}{ EFA 3.2 reference } \\
\hline & Recenzent 1: & PhDr. Lenka Krejčová, Ph.D. \\
\hline & Recenzent 2: & \\
\hline & Konzultující editor: & PhDr. Daniel Dostál, Ph.D. \\
\hline & Vedoucí editor: & Mgr. Jaroslav Gottfried \\
\hline & $\begin{array}{l}\text { Vedoucí editor aktualizace: } \\
\text { (pouze v př́ípadě aktualizací) }\end{array}$ & \\
\hline & $\begin{array}{l}\text { Editor aktualizace: } \\
\text { (pouze v př́padě aktualizací) }\end{array}$ & \\
\hline & Datum vzniku této recenze: & 3. 1.2017 \\
\hline 1.1 & Název nástroje (lokální verze): & $\begin{array}{l}\text { Test pro identifikaci nadaných žáků } \\
\text { v matematice (verze pro 3.-5. ročník) }\end{array}$ \\
\hline & Zkrácená verze názvu testu: & $\mathrm{TIM}^{3-5}$ \\
\hline 1.2 & $\begin{array}{l}\text { Původní název testu (pokud je lokální } \\
\text { verze adaptací): }\end{array}$ & \\
\hline 1.4 & Autoři původního testu: & $\begin{array}{l}\text { Hynek Cígler, Michal Jabůrek, Ondřej } \\
\text { Straka, Šárka Portešová }\end{array}$ \\
\hline 1.3 & Autoři lokální adaptace: & \\
\hline 1.7 & Lokální distributor/vydavatel testu: & Masarykova univerzita \\
\hline 1.8 & $\begin{array}{l}\text { Vydavatel původní verze testu (pokud je } \\
\text { jiný než současný distributor/vydavatel): }\end{array}$ & \\
\hline 1.9.1 & Datum vydání současné revize/vydání: & 2017 \\
\hline 1.9 .2 & $\begin{array}{l}\text { Datum vydání adaptace pro lokální } \\
\text { užívání: }\end{array}$ & \\
\hline 1.9 .3 & Datum vydání původního testu: & \\
\hline
\end{tabular}




\section{Obecný popis nástroje}

Test pro identifikaci nadaných žáků v matematice pro 3. - 5. tř́du (dále TIM ${ }^{3-5}$ ) je v souladu se svým názvem určen pro zmapování matematického nadání žáků prvního stupně základní škol, konkrétně ve 3. - 5. ročníku. Primárně vznikl pro děti, u nichž je nadání předpokládáno, nikoli pro celkovou populaci žáků v uvedeném věku.

Je administrován metodou „tužka - papír“, lze ho využít k individuální i skupinové diagnostice. Pro účely skupinové diagnostiky, resp. rediagnostiky jedince, byly vytvořeny dvě paralelní verze. Test obsahuje 25 položek, jež mají všechny charakter početní operace. V závislosti na způsobu řešení úlohy jsou některé skórovány 0 či 1 (správná versus nesprávná odpověd'), jiné 0,1 či 2 body ( 1 bod značí odpověd', která není zcela přesná, avšak svědčí pro matematické uvažování a adekvátní postup řešení, ale s určitými nedostatky či nepřesnostmi).

Vyhodnocení výsledků je možné provést manuálně, nebo za využití online aplikace. Hrubý skór, jenž je prostým součtem bodů za správně řešené položky, je převáděn na percentily, T-skóry, W-skóry a RPI-1 index. Výsledky probanda jsou tak porovnávány jak s jeho vrstevnickou skupinou, tak v rámci jeho vlastního individuálního profilu. U každé položky online aplikace dále vygeneruje pravděpodobnost správné či chybné odpovědi u konkrétního jedince a současně vyznačí takové položky, které jsou v kontextu dalších řešených úloh zodpovězeny nečekaným způsobem.

Uživatel má k dispozici Testovací sešity, Vyhodnocovací listy, Uživatelskou příručku, Psychometrický manuál a vstup do online aplikace, v níž jsou veškeré uvedené materiály rovněž ke stažení, a především zde probíhá evidence a zpracování výsledků jednotlivých probandů. Každý uživatel má vytvořen individuální účet, takže může mít data svých probandů kdykoliv k dispozici online, nebo exportovaná ve formátu PDF.

\section{Část 2:}

\section{Klasifikace}

\begin{tabular}{|c|c|c|}
\hline 1.10 .1 & Obsahová doména & $\begin{array}{ll} & \text { Školní schopnosti } \\
\square & \text { Všeobecné schopnosti } \\
\square & \text { Verbální schopnosti } \\
\bigotimes & \text { Numerické schopnosti } \\
\square & \text { Prostorové schopnosti } \\
\square & \text { Neverbální schopnosti } \\
\square & \text { Rychlost vnímání } \\
\square & \text { Pamět' } \\
\square & \text { Manuální zručnost } \\
\square & \text { Osobnost - Rys } \\
\square & \text { Osobnost - Typ } \\
\square & \text { Osobnost - Stav } \\
\square & \text { Kognitivní styly } \\
\square & \text { Motivace } \\
\square & \text { Hodnoty } \\
\square & \text { Zájmy } \\
\square & \text { Přesvědčení } \\
\square & \text { Poruchy a patologie } \\
\square & \text { Skupinové procesy } \\
\square & \text { Rodina } \\
\square & \text { Organizace, její fungování, agregovaná } \\
\text { měření, klima atd. } \\
\square \text { Školní nebo výchovné funkce } \\
\square \text { Jiné }\end{array}$ \\
\hline
\end{tabular}




\begin{tabular}{|c|c|c|}
\hline 1.10 .2 & $\begin{array}{l}\text { Zamýšlená(é) nebo hlavní oblast(i) } \\
\text { použití. }\end{array}$ & $\begin{array}{ll} & \text { Klinická psychologie } \\
\square & \text { Neuropsychologie } \\
\square & \text { Forenzní psychologie } \\
\bigotimes & \text { Psychologie výchovy a vzdělávání } \\
\square & \text { Psychologie práce a personalistika } \\
\square & \text { Poradenství, doporučení, vedení a volba } \\
& \text { povolání } \\
\square & \text { Psychologie zdraví, životní styl a životní } \\
& \text { spokojenost } \\
\square & \text { Sporty a volný čas } \\
\square & \text { Jiné }\end{array}$ \\
\hline 1.10 .3 & $\begin{array}{l}\text { Zamýšlený způsob použití } \\
\text { (podmínky, za jakých byl nástroj } \\
\text { standardizován a validizován) }\end{array}$ & $\begin{array}{l}\square \text { Nesupervidovaná administrace bez } \\
\text { kontroly nad identitou respondenta a bez } \\
\text { úplné kontroly nad podmínkami } \\
\text { administrace (např. volně př́stupný test na } \\
\text { internetu, test dostupný ke koupi v } \\
\text { knihkupectví). } \\
\square \text { Kontrolovaný nesupervidovanou } \\
\text { administrcí. Kontrola nad podmínkami (čas } \\
\text { atd.) a určitá kontrola nad identitou } \\
\text { uživatele testu (např. testy administrované } \\
\text { přes internet, ale pouze známým osobám - } \\
\text { př́ístup omezený heslem). } \\
\text { Supervidovaná a kontrolovaná } \\
\text { administrace. Administrace testu pod } \\
\text { kontrolou kvalifikovaného adminitrátora } \\
\text { nebo dohlízitele. } \\
\square \text { Řízená administrace. Administrace testu } \\
\text { prováděná pouze přes určená testovací } \\
\text { centra (napřr. programy hodnocení licencí a } \\
\text { certifikace). }\end{array}$ \\
\hline 1.10 .4 & $\begin{array}{l}\text { Popis populací, pro které je test } \\
\text { určen: }\end{array}$ & $\begin{array}{l}\text { Žáci 3.-5. tř́dy základní školy s nadprůměrnými } \\
\text { matematickými schopnostmi (třet'áci cca od } 50 . \\
\text { percentilu, čtvrt'áci od } 30 \text {. a pát'áci téměř } \\
\text { v celém rozsahu). }\end{array}$ \\
\hline 1.10 .5 & $\begin{array}{l}\text { Počet škál a krátký popis proměnné } \\
\text { nebo proměnných měřených } \\
\text { nástrojem }\end{array}$ & Matematické usuzování v pásmu nadprůměru. \\
\hline 1.11 & Formát položek & $\begin{array}{ll} & \text { Otevřený } \\
\square & \text { Mnohonásobná volba, alternativy na stejné } \\
& \text { škále } \\
\square & \text { Bipolární adjektiva } \\
\square & \text { Likertovy ratingy (škály) } \\
\square & \text { Nucená volba, alternativy na smíšených } \\
\text { škálách (ipsativní) - vysvětlení viz } \\
\text { Poznámky } \\
\square \quad \text { Mnohonásobná volba, alternativy na } \\
\text { smíšených škálách (ipsativní) - vysvětlení } \\
\text { viz Poznámky } \\
\square \quad \text { Sady párů adjektiv (sémantický } \\
\text { diferenciál), smíšené škály (ipsativní) } \\
\square \quad \text { Jiné }\end{array}$ \\
\hline 1.12 & Počet položek testu: & 25 \\
\hline
\end{tabular}




\begin{tabular}{|c|c|c|c|c|}
\hline 1.13 & Způsob(y) administrace: & $\begin{array}{l}\square \\
\square \\
\square \\
\square \\
\square \\
\square \\
\square\end{array}$ & \multicolumn{2}{|c|}{$\begin{array}{l}\text { Interaktivní individuální administrace } \\
\text { Supervidovaná skupinová administrace } \\
\text { Počítačová lokálně nainstalovaná aplikace - } \\
\text { pod supervizí/dohledem } \\
\text { Počítačová aplikace na webu - pod } \\
\text { supervizí/dohledem } \\
\text { Počítačová lokálně nainstalovaná aplikace - } \\
\text { bez supervise/testování sebe } \\
\text { Počítačová aplikace na webu - bez } \\
\text { supervize/testování sebe } \\
\text { Jiné }\end{array}$} \\
\hline 1.14 & Způsob odpovídání: & $\begin{array}{l}\square \\
\square \\
\square \\
\square \\
\square\end{array}$ & \multicolumn{2}{|c|}{$\begin{array}{l}\text { Ústní rozhovor } \\
\text { Papír a tužka } \\
\text { Manuální operace } \\
\text { Na počítači } \\
\text { Jiné }\end{array}$} \\
\hline 1.15 & 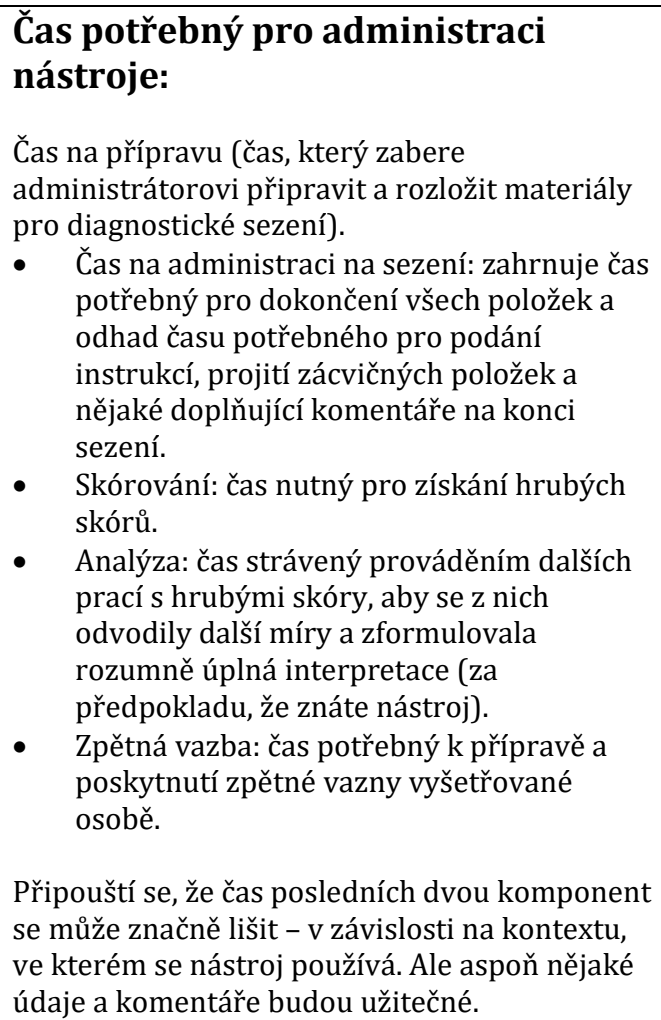 & & $\begin{array}{l}\text { Administrace: } \\
\text { Skórování: } \\
\text { Analýza: } \\
\text { Zpětná vazba: } \\
\text { Čas na analýzu } \\
\text { odhadnut. }\end{array}$ & $\begin{array}{l}2 \text { minuty (tisk pracovních } \\
\text { sešitů a instrukce) } \\
45 \text { minut } \\
10 \text { minut } \\
- \\
- \\
\text { a zpětnou vazbu nebyl }\end{array}$ \\
\hline 1.16 & $\begin{array}{l}\text { Jsou k dispozici různé formy } \\
\text { nástroje? }\end{array}$ & \multicolumn{3}{|c|}{$\begin{array}{l}\text { Dvě paralelní formy A a B určené pro retest } \\
\text { či pro účely skupinové administrace. }\end{array}$} \\
\hline
\end{tabular}




\section{Část 3:}

\section{Měření a skórování}

\begin{tabular}{|c|c|c|}
\hline 1.17 & Procedura skórování testu: & 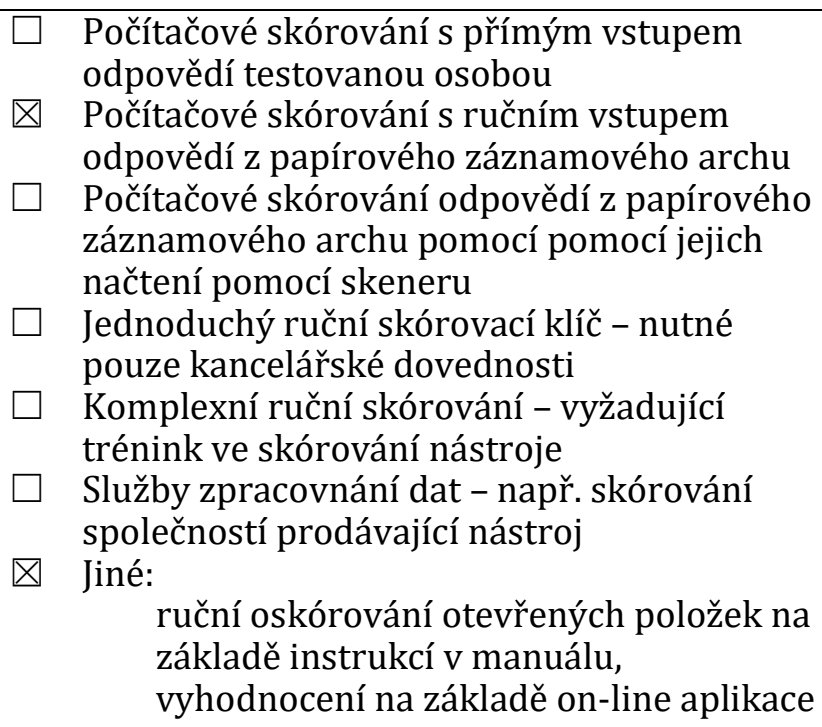 \\
\hline 1.18 & Skóry: & $\begin{array}{l}0,1 \text { a v některých případech } 2 \text { body za každou } \\
\text { položku podle míry její správnosti. } \\
\text { U přeskočených položek skór } 9 \text {. } \\
\text { Poskytnuté skóry obsahují validizační ukazatele } \\
\text { hodnotí pravděpodobnost pozorovaných } \\
\text { odpovědí při odhadnuté míře latentního rysu } \\
\text { respondenta. }\end{array}$ \\
\hline 1.19 & $\begin{array}{l}\text { Transformace skóru na standardní } \\
\text { skóry: }\end{array}$ & $\begin{array}{ll}\text { 区 } & \text { Normalizovaná - skóry se získají použitím } \\
\text { normalizační tabulky } \\
\square \quad \begin{array}{l}\text { Nenormalizovaná - skóry se získají lineární } \\
\text { transformací }\end{array}\end{array}$ \\
\hline 1.20 & Použité škály & 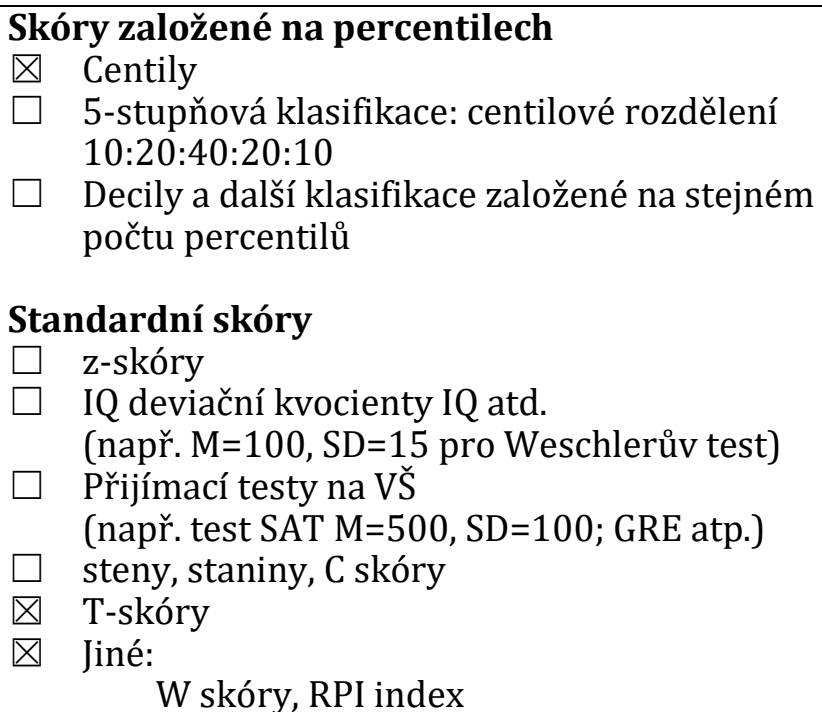 \\
\hline
\end{tabular}




\section{Část 4:}

\section{Počítačově generované zprávy}

Toto je čistě popisné. Hodnocení zpráv bude součástí části recenze nazvané Hodnocení.

\begin{tabular}{|l|l|ll|}
\hline 1.21 & $\begin{array}{l}\text { Jsou počítačově generované zprávy } \mathbf{k} \\
\text { dispozici s nástrojem? }\end{array}$ & $\square \quad$ Ano \\
& $\bigotimes \quad \mathrm{Ne}$ \\
\hline
\end{tabular}

\section{Část 5:}

\section{Nabídka, podmínky a náklady}

Tato část definuje, co vydavatel poskytne, komu, za jakých podmínek a za jaké ceny. Definuje podmínky kladené dodavatelem a týkající se toho, kdo smí a kdo nesmí získat materiál nástroje. Pokud jedna z možností neodpovídá podmínkám nabídky, doplňte popis relevantních podmínek.

\begin{tabular}{|c|c|c|}
\hline 1.23 & $\begin{array}{l}\text { Dokumentace poskytovaná } \\
\text { distributorem jako součást } \\
\text { testového balíku }\end{array}$ & 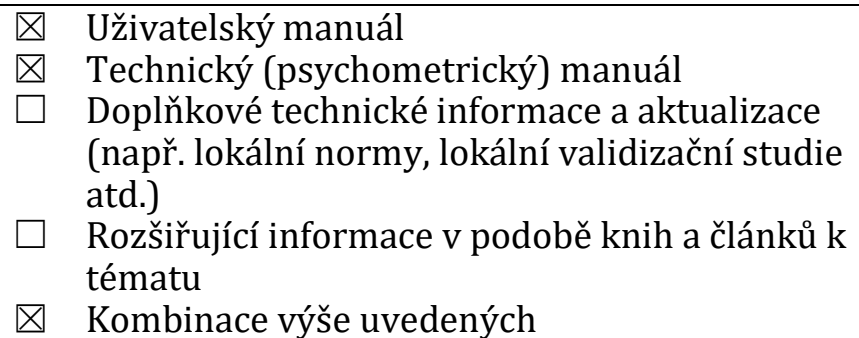 \\
\hline 1.24 & Metody publikace & $\begin{array}{ll}\square & \text { Papír } \\
\square & \text { PC - Diskety } \\
\square & \text { PC - CD/ROM } \\
\bigotimes & \text { Download z internetu } \\
\bigotimes & \text { Živý internet (nástroj pracuje v internetovém } \\
& \text { prohlížeči) } \\
\square & \text { Jiné }\end{array}$ \\
\hline 1.25 .1 & $\begin{array}{l}\text { Počáteční náklady. } \\
\text { Cena kompletní sady materiálů (v̌̌echny manuály a } \\
\text { dalš́ material nutný k asponn jedné zkušsbní } \\
\text { administraci). Kolik uchazeču lze vyšetrovat pomocí } \\
\text { materiáluz získaných za počátečń náklady, kde tyto } \\
\text { náklady zahrnují materiály pro opakované vyšetření. }\end{array}$ & $\begin{array}{l}\text { 2000,- Kč (test má licencí neomezené množství } \\
\text { použití) }\end{array}$ \\
\hline 1.25 .2 & Opakující se náklady: & $\begin{array}{l}\text { 500,-Kč za roční prodloužení licence testu. } \\
\text { Náklady na vlastní tisk pracovních listů. }\end{array}$ \\
\hline 1.26 .1 & $\begin{array}{l}\text { Ceny za zprávy generované } \\
\text { softwarem nainstalovaným } \\
\text { uživatelem: }\end{array}$ & NA \\
\hline 1.26 .2 & $\begin{array}{l}\text { Ceny za vyhotovení zprávy zaslené } \\
\text { prostřednictvím pošty/faxu: }\end{array}$ & NA \\
\hline 1.26 .3 & $\begin{array}{l}\text { Ceny za vyhotovení zprávy zaslené } \\
\text { prostřednictvím internetové služby: }\end{array}$ & NA \\
\hline
\end{tabular}




\begin{tabular}{|c|c|c|c|}
\hline 1.27 & $\begin{array}{l}\text { Ceny za další služby a zpracování } \\
\text { dat: opravy nebo vývoj } \\
\text { automatických zpráv: }\end{array}$ & NA & \\
\hline 1.28 & 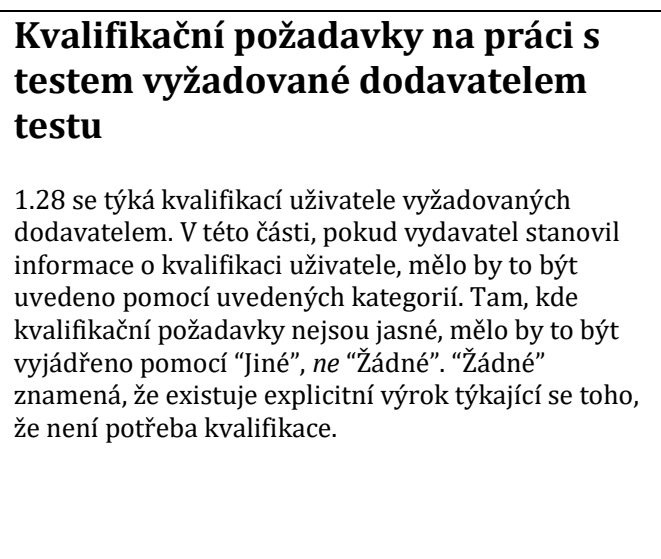 & $\begin{array}{l}\bigotimes \\
\square \\
\square \\
\square \\
\square \\
\square \\
\square\end{array}$ & $\begin{array}{l}\text { Žádné } \\
\text { Oprávnění (certifikát) pro specifický test } \\
\text { Oprávnéní (certifikát) pro obecné výkonové } \\
\text { testy: i. e. míry maximálního výkonu ve } \\
\text { schopnostech } \\
\text { Potvrzení v testování obecných schopností a } \\
\text { dovedností: míry maximálního výkonu ve } \\
\text { vztahu k potenciálu k výkonu } \\
\text { Potvrzení v obecné diagnostice a diagnostice } \\
\text { osobnosti: míry typického chování, postojů a } \\
\text { preferencí } \\
\text { Jiné }\end{array}$ \\
\hline 1.29 & 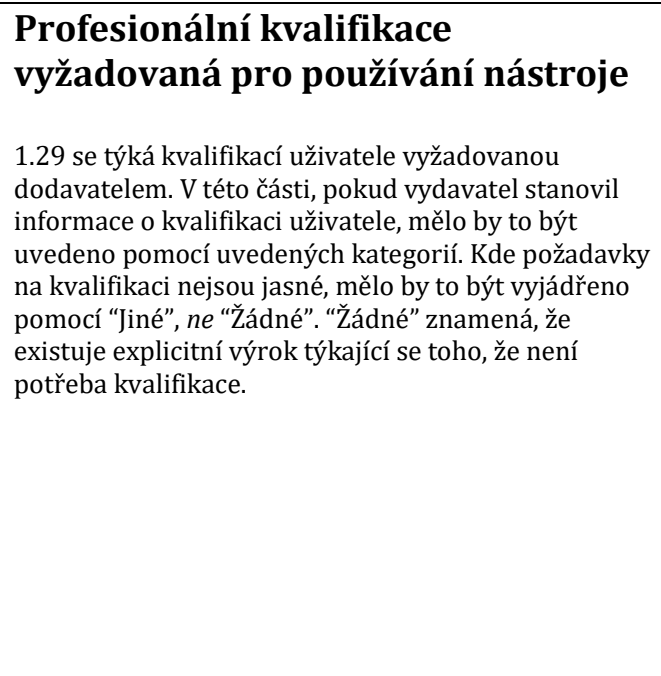 & $\begin{array}{l}\square \\
\square \\
\square \\
\square \\
\square \\
\square \\
\square \\
\square \\
\square\end{array}$ & $\begin{array}{l}\text { Žádné } \\
\text { Praktický psycholog s kvalifikací v relevantní } \\
\text { aplikační oblasti } \\
\text { Praktický psycholog } \\
\text { Výzkumný psycholog } \\
\text { Nepsychologický akademický výzkumník } \\
\text { Praktik v relevantních příbuzných profesích } \\
\text { (terapie, medicína, poradenství, vzdělání, } \\
\text { lidské zdroje atd.) } \\
\text { Držitel Certifikátu způsobilosti pro testování } \\
\text { v psychologii práce A BPS } \\
\text { Držitel Certifikátu způsobilosti pro testování } \\
\text { v oblastni vzdělávacím A BPS } \\
\text { Držitel Certifikátu způsobilosti pro testování } \\
\text { v psychologii práce B BPS } \\
\text { Jiné }\end{array}$ \\
\hline
\end{tabular}

\section{Část 6:}

\section{Hodnocení testových materiálů}

\section{Vysvětlení hodnocení}

V následujících částech jsou celková posouzení adekvátnosti informací týkajících se validity, reliability a norem zobrazeny automaticky tučně.

Jakýkoli nástroj s jedním nebo více posouzeními 0 nebo 2 týkajícími se atributů považovaných za kritické pro bezpečné používání nástroje, by neměl být považován za nástroj, který splňuje minimální standardy. 


\begin{tabular}{|c|c|c|c|}
\hline $\begin{array}{l}\text { Vstup na posuzovacím } \\
\text { formuláři }\end{array}$ & $\begin{array}{c}\text { Posouzení podle standardů } \\
\text { EFPA }\end{array}$ & Reprezentace recenze $\mathrm{v} U \mathrm{UK}$ & Vysvětlení \\
\hline$[\mathrm{n} / \mathrm{a}]$ & {$[\mathrm{n} / \mathrm{a}]$} & [n/a ] & $\begin{array}{l}\text { Tento atribut není u tohoto } \\
\text { nástroje použitelný }\end{array}$ \\
\hline $\mathbf{0}$ & {$[-]$} & [None ] & $\begin{array}{c}\text { Není možné posoudit jako ne } \\
\text { nebo nedostatek } \\
\text { poskytnutých informací }\end{array}$ \\
\hline 1 & {$[-1]$} & {$\left[\begin{array}{ll}* & ]\end{array}\right.$} & Neadekvátní \\
\hline 2 & & {$\left[\begin{array}{ll}* * & ]\end{array}\right]$} & NYNÍ NEPOUŽÍVÁNO \\
\hline 3 & {$\left[\begin{array}{ll}0 & 0\end{array}\right]$} & {$[* * *]$} & Adekvátní nebo přiměřený \\
\hline 4 & [ 1 ] & [**** ] & Dobrý \\
\hline 5 & {$\left[\begin{array}{ll}2 & ]\end{array}\right.$} & {$[* * * * *]$} & Vynikající \\
\hline & & $\begin{array}{c}\text { [N.r.i.o.r] } *^{*} \text { (pouze pro } \\
\text { aktualizace) }\end{array}$ & $\begin{array}{l}\text { Položka nebyla v původní } \\
\text { recenzi posuzována }\end{array}$ \\
\hline
\end{tabular}

V této části má být provedeno více hodnocení různých aspektů nebo atributů dokumentace dodávané s nástrojem (nebo balíkem). Termín „dokumentace“ byl vybrán, aby pokrýval všechny ty materiály dodávané s nástrojem nebo snadno dostupné kvalifikovanému uživateli: nap̌r. manual administrátora; technické př́ručky; brožury s normami; dodatky k manuálu; aktualizace od vydavatelů/dodavatelů atd.

Položky mají být posuzovány n/a nebo 0 až 5 (poloviční rating je přijatelný)

\begin{tabular}{|c|c|c|}
\hline \multirow{2}{*}{\multicolumn{2}{|c|}{ 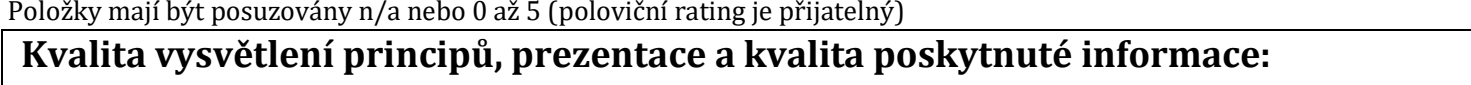 }} & \multirow{3}{*}{$\begin{array}{r}\text { Kaling } \\
5 \\
5\end{array}$} \\
\hline & & \\
\hline 2.1 & Celkový rating kvality vysvětlení principů: & \\
\hline 2.1 .1 & i) Teoretické základy konstruktů: & 5 \\
\hline 2.1 .2 & ii) Procedura vývoje testu: & 5 \\
\hline 2.1 .3 & iii) Důkladnost analýz položek a model analýzy položek: & 5 \\
\hline 2.1 .4 & iv) Vysvětlení obsahové validity: & 5 \\
\hline 2.1 .5 & v) Souhrn relevantního výzkumu: & 5 \\
\hline 2.2 & 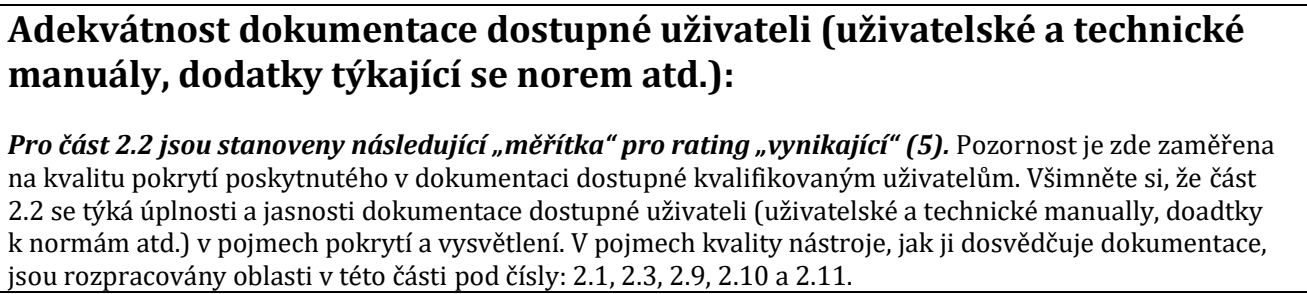 & 5 \\
\hline 2.2 .1 & $\begin{array}{l}\text { Principy: [viz 2.1] } \\
\text { Dobře argumentovaný a jasně prezentovaný popis toho, co má podle návrhu měřit a proč byl zkonstruován } \\
\text { tak, jak je. }\end{array}$ & 5 \\
\hline 2.2 .2 & $\begin{array}{l}\text { Vývoj: } \\
\text { Úplné detaily týkajíć se zdrojů položek, pilotáže, analýz položek, srovnávacích studií a změn prováděných v } \\
\text { průběhu vývojových pokusủ. }\end{array}$ & 5 \\
\hline 2.2 .3 & $\begin{array}{l}\text { Standardizace: } \\
\text { Jasné a detailní informace poskytnuté o velikostech a zdrojích standardizačního souboru a standardizační } \\
\text { proceduře. }\end{array}$ & 5 \\
\hline 2.2 .4 & $\begin{array}{l}\text { Normy: } \\
\text { Jasné a detailní informace poskytnuté o velikostech a zdrojích normalizačních skupin, podmínkách vyšetření } \\
\text { atd. }\end{array}$ & 5 \\
\hline 2.2 .5 & $\begin{array}{l}\text { Reliabilita: } \\
\text { Dobré vysvětlení reliability a široký rozsah měr vnitřní konsistence a retestu spolu s vysvětlením jejich } \\
\text { relevance a zobecnitelnosti nástroje vyšetření. }\end{array}$ & 5 \\
\hline 2.2 .6 & $\begin{array}{l}\text { Validita: } \\
\text { Dobré vysvětlení validity spolu s širokou škálou studií jasně a poctivě popsaných. }\end{array}$ & 5 \\
\hline 2.3 & Kvalita procedurálních instrukcí poskytnutých uživateli: & 5 \\
\hline 2.3 .1 & $\begin{array}{l}\text { Pro administraci testu: } \\
\text { Poskytnutá jasnáa a detailní vysuětlení a procedurální průvodce krok za krokem spolu s dobrými radami } \\
\text { týkajíććcmi se otázek uchazečú a problémových situací. }\end{array}$ & 5 \\
\hline
\end{tabular}




\begin{tabular}{|c|c|c|}
\hline 2.3 .2 & $\begin{array}{l}\text { Pro skórování testu, normy atd.: } \\
\text { Poskytnuté jasné a detailní informace spolu s popsanými kontrolami pro vyhnutí se možným chybám } \\
\text { skórování. }\end{array}$ & 5 \\
\hline 2.3 .3 & $\begin{array}{l}\text { Pro interpretaci a vytváření zpráv: } \\
\text { Detailní doporučení týkajííí se interpretace různých skórůo, chápání normativních měr a zacházení se vztahy } \\
\text { mezi různými škálami, s množstvím ilustrativních příkladú a př́padových studií. }\end{array}$ & 4 \\
\hline 2.3 .4 & $\begin{array}{l}\text { Pro poskytnutí zpětné vazby a debriefingu respondentům testu a dalším: } \\
\text { Detailní doporučení, jak prezentovat zpětnou vazbu uchazečǔm. }\end{array}$ & 4 \\
\hline 2.3 .5 & $\begin{array}{l}\text { Pro poskytování dobrých praktických témat týkajících se poctivosti a } \\
\text { zkreslení: } \\
\text { svedení detailních informací o studiích sexuálního a etnického zkreslení s relevantními varováními týkajicími } \\
\text { se použivání a zobecnováni validit. }\end{array}$ & 5 \\
\hline 2.3 .6 & $\begin{array}{l}\text { Omezení používání: } \\
\text { Jasné popisy, kdo by měl a kdo by neměl být vyšetřován spolu s dobře vysvětlenými odůvodněními těchto } \\
\text { omezení (např. typy nezpǔsobilostí, požadované úrovně gramotnosti atd.). }\end{array}$ & 5 \\
\hline 2.3 .7 & $\begin{array}{l}\text { Reference a podpůrné materiály: } \\
\text { Detailní odkazy na relevantní podpůrnou akademickou literature a křížové odkazy na další př́ibuzné } \\
\text { materially týkajííi se diagnostických nástrojủ. }\end{array}$ & 5 \\
\hline \multicolumn{2}{|r|}{ Kvalita materiálů: } & 5 \\
\hline 2.4 & $\begin{array}{l}\text { Všeobecná kvalita materiálů testu } \\
\text { (testové brožury, odpověd'ové archy, testové objekty, software atd.): }\end{array}$ & 5 \\
\hline 2.5 & Kvalita lokální adaptace testu (pokud byl test přeložen a adaptován do místního jazyka): & [n/a] \\
\hline 2.6 & Snadnost, s jakou může respondent testu porozumět úkolu: & 5 \\
\hline 2.7 & $\begin{array}{l}\text { Snadnost, s jakou mohou být respondentem testu tvořeny reakce nebo } \\
\text { odpovědi: }\end{array}$ & 5 \\
\hline 2.8 & Kvalita položek: & 5 \\
\hline \multicolumn{3}{|c|}{ Recenzentovy komentáře týkající se dokumentace: } \\
\hline \multicolumn{3}{|c|}{$\begin{array}{l}\text { Autoři postupovali při vývoji testu velmi pečlivě, systematicky, s jasnou vizí, pro koho a jak bude test } \\
\text { využíván. V uživatelské př́ručce jsou představena klíčová teoretická východiska konstruování testu. } \\
\text { Na základě širokého okruhu odborné literatury je vymezen koncept matematického nadání. Autoři } \\
\text { současně přesně deklarují, který přístup pokládali za relevantní při tvorbě svého nástroje. } \\
\text { Za pozoruhodné pokládám, jakým způsobem byl výběr položek testu realizován. Finální soubor } \\
\text { dvaceti pěti testových úloh ve dvou paralelních verzích byl složen na základě analýzy výsledků } \\
\text { rozsáhlého souboru probandů (více než dvě stě dětí z příslušné cílové skupiny), kteří zpracovávali } 62 \\
\text { různých položek. Prostřednictvím důsledné položkové analýzy byly nakonec určeny úlohy, jež se staly } \\
\text { součástí testu. }\end{array}$} \\
\hline
\end{tabular}


Rating

\section{Informace o normách nebo referenční skupině}

\begin{tabular}{|c|c|c|c|}
\hline 2.9 & Celková adekvátı & tnost: & 5 \\
\hline 2.9 .1 & $\begin{array}{cc}\text { Vhodnost pro loká } \\
\text { [n/a] } & \mathrm{N} \\
0 & \check{Z}_{\text {a }} \\
1 & \mathrm{~N} \\
3 & \mathrm{~L} \\
& \mathrm{p} \\
4 & \mathrm{~V} \\
& \mathrm{re} \\
5 & \mathrm{~V} \\
& \mathrm{~d}\end{array}$ & $\begin{array}{l}\text { xální použití, at' už pro lokální nebo mezinárodní normy: } \\
\text { Nepoužitelné } \\
\text { Žádná informace nepodána. } \\
\text { Není lokálně relevantní (např. nevhodné zahraniční výběry). } \\
\text { Lokální výběr z obecné populace nebo nelokální normy, které lze } \\
\text { použít s varováním. } \\
\text { Výběry lokální země nebo relevantní mezinárodní výběry s dobrou } \\
\text { relevancí pro zamýšlenou aplikaci. } \\
\text { Výběry lokální země nebo relevantní mezinárodní výběry vybrané z } \\
\text { dobřre definovaných výběrů z relevantních aplikačních oblastí. }\end{array}$ & 5 \\
\hline 2.9 .2 & $\begin{array}{cc}\text { Vhodnost pro zam } \\
\text { [n/a] } & \mathrm{N} \\
0 & \check{\mathrm{Z}}_{\text {a }} \\
1 & \mathrm{~N} \\
3 & \mathrm{~A} \\
& \text { ta } \\
4 & \mathrm{D} \\
5 & \mathrm{~V} \\
& \mathrm{a} \\
& \mathrm{sr} \\
& \end{array}$ & $\begin{array}{l}\text { mýšlené aplikace: } \\
\text { Nepoužitelné } \\
\text { Žádná informace nepodána. } \\
\text { Norma nebo normy nejsou adekvátní pro zamýšlené aplikace. } \\
\text { Adekvátní normy pro obecnou populaci a/nebo rozmezí normativních } \\
\text { tabulek. } \\
\text { Dobré rozmezí normativních tabulek. } \\
\text { Vynikajíć rozmezí výběrově relevantních norem vztahujících se k věku } \\
\text { a pohlaví, s informacemi o dalších rozdílech v rámci skupin (např. } \\
\text { směs etnických skupin). }\end{array}$ & 5 \\
\hline $\begin{array}{l}2.9 .3 \\
\end{array}$ & \begin{tabular}{cc}
\multicolumn{2}{l}{ Velikosti výběrů: } \\
{$[\mathrm{n} / \mathrm{a}]$} & $\mathrm{N}$ \\
0 & $\check{\mathrm{Z}}$ \\
1 & $\mathrm{~N}$ \\
3 & $\mathrm{~A}$ \\
4 & $\mathrm{~V}$ \\
5 & $\mathrm{~V}$ \\
\end{tabular} & $\begin{array}{l}\text { Nepoužitelné } \\
\text { Žádná informace nepodána. } \\
\text { Neadekvátní výběry (např. méně než 150). } \\
\text { Adekvátní výběry (např́. 150-300). } \\
\text { Velké výběry (např. 300-1000). } \\
\text { Velmi velké výběry (např. 1000+). }\end{array}$ & 4 \\
\hline 2.9 .4 & \begin{tabular}{cr}
\multicolumn{2}{c}{ Procedury použité } \\
$\square$ & Ž $_{:}$ \\
$\square$ & $\mathrm{R}$ \\
$\square$ & $\mathrm{N}$ \\
$\square$ & $\mathrm{N}$ \\
\end{tabular} & $\begin{array}{l}\text { té při výběru souboru: } \\
\text { Žádná informace neposkytnuta } \\
\text { Reprezentativní populaci [sumarizujte kritéria] } \\
\text { Nahodilá } \\
\text { Náhodná }\end{array}$ & 5 \\
\hline 2.9 .5 & $\begin{array}{cr}\text { Kvalita informací } \\
\text { vlivech věku, rodu } \\
\text { [n/a] } & \mathrm{N} \\
0 & \check{\mathrm{Z}} \\
1 & \mathrm{~N} \\
3 & \mathrm{~A} \\
4 & \mathrm{D} \\
5 & \mathrm{~V} \\
& \mathrm{SE} \\
\end{array}$ & $\begin{array}{l}\text { Í poskytnutých o minoritní/chráněné skupině, rozdílech, } \\
\text { lu atd.: } \\
\text { Nepoužitelné } \\
\text { Žádná informace nepodána. } \\
\text { Neadekvátní informace. } \\
\text { Adekvátní obecné informace s minimální analýzou. } \\
\text { Dobré popisy a analýzy skupin a rozdílů } \\
\text { Vynikající série analýz a diskuse o relevantních tématech vztahujících } \\
\text { se k použití a interpretaci. }\end{array}$ & 5 \\
\hline \multicolumn{4}{|c|}{ 2.9.6 Komentáře recenzentů k normám: } \\
\hline \multicolumn{4}{|c|}{$\begin{array}{l}\text { Pro tvorbu norem byl využit soubor bezmála osmi set probandů z různých krajů České republiky, ze } \\
\text { všech tří postupových ročníkủ základní školy, pro něž je metoda určena. V různých časech byly } \\
\text { administrovány obě paralelní formy testu. Veškerá získaná data byla detailně analyzována, aby bylo } \\
\text { prověřeno, že normy v obou formách a pro všechny věkové kategorie uvádějí adekvátní údaje. }\end{array}$} \\
\hline
\end{tabular}




\section{Validita}

\begin{tabular}{|c|c|c|}
\hline 2.10 & $\begin{array}{l}\text { Celková adekvátnost: (Tento celkový rating se získá na základě posouzení hodnot ratingů } \\
\text { daných v položkách } 2.10 .1-2.10 .2 .4 \text {. Neprůměrujte pouze čísla, abyste získali celkový rating. } \\
\text { Obvykle bude roven bud' konstruktové validitě nebo validitě vztahující se ke kritériu, podle } \\
\text { toho, která z nich je vyšší.) }\end{array}$ & 5 \\
\hline 2.10 .1 & Konstruktová validita - celková adekvátnost & 5 \\
\hline 2.10 .1 .1 & $\begin{aligned} \text { Použité plány: } \\
\square \quad \text { Žádná informace nepodána } \\
\square \quad \text { Korelace s dalšími nástroji a výkonovými kritérii } \\
\square \quad \text { Vnitroškálový (korelace položky se zbytkem) } \\
\square \quad \text { Rozdíly mezi skupinami } \\
\square \quad \text { Matice mnoha rysů a mnoha metod (MTMM) } \\
\square \quad \text { Explorační faktorová analýza } \\
\square \quad \text { Konfirmační faktorová analýza } \\
\square \quad \text { Experimentální plány } \\
\square \quad \text { Jiné }\end{aligned}$ & \\
\hline 2.10.1.2 & $\begin{array}{cl}\begin{array}{c}\text { Velikosti výběrů: } \\
0\end{array} & \text { Žádná informace neposkytnuta. } \\
1 & \text { Jedna neadekvátní studie (např. velikost výběru menší než 100). } \\
3 & \text { Jedna adekvátní studie (např. velikost výběru 100-200). } \\
4 & \text { Více než jedna adekvátní nebo velká studie. } \\
5 & \text { Dobrá série adekvátních až rozsáhlých studií. } \\
\end{array}$ & 5 \\
\hline 2.10.1.3 & $\begin{aligned} \text { Procedura výběru souboru: } \\
\square \quad \text { Žadná informace neposkytnuta } \\
\square \quad \text { Reprezentativní vůči populaci [sumarizujte kritéria] } \\
\square \quad \text { Nahodilá } \\
\square \quad \text { Náhodná } \\
\end{aligned}$ & \\
\hline 2.10 .1 .4 & $\begin{array}{cl}\begin{array}{c}\text { Medián a rozsah korelací mezi testem a dalšími podobnými testy: } \\
0\end{array} & \text { Žádná informace neposkytnuta. } \\
1 & \text { Neadekvátní }(\mathrm{r}<0.55) . \\
3 & \text { Adekvátní }(0.55<\mathrm{r}<0.65) \\
4 & \text { Dobrý }(0.65<\mathrm{r}<0.75) . \\
5 & \text { Vynikající }(\mathrm{r}>0.75) \\
\end{array}$ & 3 \\
\hline 2.10 .1 .5 & $\begin{array}{cl}\text { Kvalita nástrojů jako kritérií nebo markerů: } \\
0 & \text { Žádná informace neposkytnuta. } \\
1 & \text { Poskytnuta neadekvátní informace. } \\
3 & \text { Adekvátní kvalita. } \\
4 & \text { Dobrá kvalita. } \\
5 & \text { Vynikající kvalita s širokým rozsahem relevantních markerů pro } \\
& \text { konvergentní a divergentní validizaci. } \\
\end{array}$ & 4 \\
\hline 2.10 .1 .6 & $\begin{array}{cl}\text { Analýzy diferenciálního fungování položek (DIF): } \\
\text { [N/A ] } & \text { Nepoužitelné } \\
0-5 & \text { hodnocení kvality DIF analýzy } \\
\end{array}$ & 4 \\
\hline 2.10 .2 & Validita vztahující se ke kritériu - celková adekvátnost & 5 \\
\hline 2.10.2.1 & $\begin{array}{c}\text { Popis použitých kritérií a charakteristik populací: } \\
\square \quad \text { Souběžná } \\
\bigotimes \quad \text { Prediktivní } \\
\square \quad \text { Postdiktivní }\end{array}$ & \\
\hline 2.10.2.2 & $\begin{array}{cl}\begin{array}{c}\text { Velikosti výběrů: } \\
0\end{array} & \text { Žádná informace neposkytnuta. } \\
1 & \text { Jedna neadekvátní studie (např. velikost výběru menší než 100). } \\
3 & \text { Jedna adekvátní studie (např. velikost výběru 100-200). } \\
4 & \text { Jedna velká nebo vice než jedna adekvátně rozsáhlá studie. } \\
5 & \text { Dobrá série adekvátních až rozsáhlých studií. } \\
\end{array}$ & 4 \\
\hline 2.10 .2 .3 & $\begin{array}{l}\text { Procedura výběru souboru: } \\
\square \quad \text { Žádná informace neposkytnuta } \\
\bigotimes \quad \text { Účelná nebo reprezentativní } \\
\square \quad \text { Nahodilá } \\
\square \quad \text { Náhodná }\end{array}$ & \\
\hline
\end{tabular}


2.10.2.4 Medián a rozsah korelací mezi testem a kritérii:

0 Žádná informace neposkytnuta.

Neadekvátní (např. $\mathrm{r}<0.2$ ).

3 Adekvátní (např. $0.2<\mathrm{r}<0.35$ ).

Dobrý (např. $0.35<\mathrm{r}<0.50$ ).

5

Vynikající (např. $r>0.50$ )

\subsubsection{Komentáře recenzenta týkající se validity:}

V současné době neexistuje $\mathrm{v}$ našem prostředí podobný typ testu, jehož výsledky by bylo možné porovnávat $\mathrm{s}$ výkony $\mathrm{v}$ testu TIM $^{3-5}$. Autoři však využili diagnostické údaje z komplexních baterií rozumových schopností, některých testů zaměřených na dílčí schopnosti, výsledky porovnávali také se školní úspěšností i hodnocením vyučujících, jež mohou posoudit matematické nadání svých žáků. Mimoto sledovali výkony skupiny dětí, jež navštěvovaly specializovaný matematický kurz. Veškerá data byla velmi důkladně a komplexně analyzována za využití sofistikovaných statistických metod. Psychometrický manuál testu obsahuje extrémní množství výstupů z těchto analýz, jež opakovaně a $\mathrm{z}$ různých hledisek potvrzují validitu metody.

\section{Reliabilita}

\begin{tabular}{|c|c|c|c|}
\hline 2.11 & \multicolumn{2}{|c|}{ Celková adekvátnost: } & 5 \\
\hline 2.11.1. & \multicolumn{3}{|c|}{$\begin{aligned} \text { Poskytnutá data týkající se reliability: } \\
\square \quad \text { Uveden pouze jeden koeficient reliability } \\
\square \quad \text { Uveden pouze jeden odhad standardní chyby měření } \\
\square \quad \text { Koeficienty reliability pro několik různých skupin } \\
\square \quad \text { Standardní chyba měření uvedená pro několik různých skupin }\end{aligned}$} \\
\hline 2.11 .1 & \multicolumn{3}{|c|}{ Vnitřní konzistence: } \\
\hline 2.11.1.1 & \multicolumn{2}{|c|}{$\begin{array}{ll}\text { Velikost výběru: } & \\
0 & \text { Neposkytnuta žádná informace. } \\
1 & \text { Jedna neadekvátní studie (napřr. rozsah výběru menší než 100). } \\
3 & \text { Jedna adekvátní studie (napřr. rozsah výběru 100-200). } \\
4 & \text { Jedna rozsáhlá nebo vice než jedna adekvátně rozsáhlá studie. } \\
5 & \text { Dobrá série adekvátních až rozsáhlých studií. } \\
{[\mathrm{N} / \mathrm{A}]} & \text { Nepoužitelné. } \\
\end{array}$} & 5 \\
\hline 2.11 .1 .2 & \multicolumn{2}{|c|}{$\begin{array}{ll}\text { Medián koeficientů: } \\
0 & \text { Neposkytnuta žádná informace. } \\
1 & \text { Neadekvátní (napřr. } r<0.7 \text { ) } \\
3 & \text { Adekvátní (např. } r=0.7 \text { až } 0.79 \text { ) } \\
4 & \text { Dobrý (např. } r=0.8 \text { až } 0.89 \text { ) } \\
5 & \text { Vynikajíć́ (např. } r>0.9 \text { ) } \\
{[\mathrm{N} / \mathrm{A}]} & \text { Nepoužitelné. } \\
\end{array}$} & 4 \\
\hline 2.11 .2 & \multicolumn{3}{|c|}{ Testová-retestová stabilita: } \\
\hline 2.11.2.1 & \multicolumn{2}{|c|}{$\begin{array}{cl}\text { Rozsah výběru: } & \\
0 & \text { Neposkytnuta žádná informace. } \\
1 & \text { Jedna neadekvátní studie (nap̌r. rozsah výběru menší než 100). } \\
3 & \text { Jedna adekvátní studie (napřr. rozsah výběru 100-200). } \\
4 & \text { Jedna rozsáhlá nebo vice ně jedna adekvátně rozsáhlá studie. } \\
5 & \text { Dobrá série adekvátních až rozsáhlých studií. } \\
\text { Medián koeficientů: }\end{array}$} & 3 \\
\hline 2.11 .2 .2 & $\begin{array}{l}\text { Medián koeficien } \\
0 \\
1 \\
3 \\
4 \\
5\end{array}$ & $\begin{array}{l}\text { Atů: } \\
\text { Neposkytnuta žádná informace. } \\
\text { Neadekvátní (napřr. } r<0.6 \text { ) } \\
\text { Adekvátní (napřr. } \mathrm{r}=0.6 \text { až 0.69) } \\
\text { Dobrý (napřr. } \mathrm{r}=0.7 \text { až 0.79) } \\
\text { Vynikající (nap̌r. } \mathrm{r}>0.8 \text { ) }\end{array}$ & 4 \\
\hline
\end{tabular}




\begin{tabular}{|c|c|c|c|}
\hline 2.11 .3 & \multicolumn{3}{|c|}{ Reliabilita jako ekvivalence: } \\
\hline 2.11.3.1 & \multicolumn{2}{|c|}{$\begin{array}{cl}\text { Rozsah výběru: } & \\
0 & \text { Neposkytnuta žádná informace. } \\
1 & \text { Jedna neadekvátní studie (např. rozsah výběru menší než 100). } \\
3 & \text { Jedna adekvátní studie (napřr. rozsah výběru 100-200). } \\
4 & \text { Jedna rozsáhlá nebo vice než jedna adekvátně rozsáhlá studie. } \\
5 & \text { Dobrá série adekvátních až rozsáhlých studií. } \\
\text { [N/A] } & \text { Nepoužitelné. }\end{array}$} & 3 \\
\hline 2.11.3.2 & $\begin{array}{l}\text { Medián koeficiel } \\
\quad 0 \\
1 \\
3 \\
4 \\
5 \\
{[\text { N/A ] }}\end{array}$ & 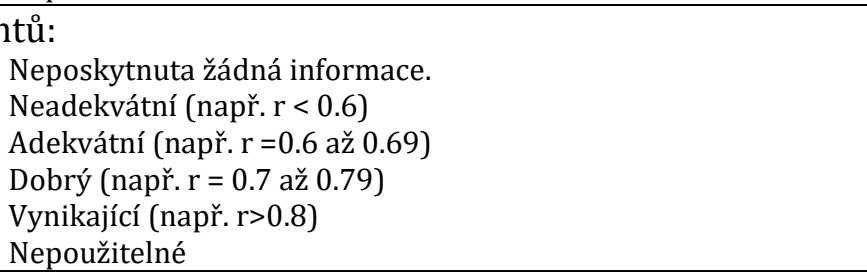 & 4 \\
\hline \multicolumn{4}{|c|}{ 2.11.4 Komentáře recenzentů k reliabilitě: } \\
\hline \multicolumn{4}{|c|}{$\begin{array}{l}\text { Test-retestová reliabilita a reliabilita paralelních forem byla ověřována v rámci pilotní studie, nebot' } \\
\text { při standardizaci proběhl sběr dat jednorázově. Porovnání výstupů z pilotní a standardizační studie } \\
\text { však ukazuje adekvátnost volby tohoto postupu. } \\
\text { Vzhledem k faktu, že metoda je určená pro zmapování matematického nadání, výsledky analýz } \\
\text { ukazují, že test lze spolehlivě použít především u žáků, jejichž matematické dovednosti se jeví } \\
\text { skutečně nadprůměrné. Autoři velmi pečlivě komentují, co test měří a za jakých okolností je namístě } \\
\text { ho využívat, v souladu s výsledky analýz. }\end{array}$} \\
\hline
\end{tabular}

\section{Část 9:}

\section{Závěrečné hodnocení:}

\subsection{Hodnotící zpráva testu:}

Celý proces vývoje testu pokládám za ukázkovou diagnostickou a psychometrickou práci. Autoři metodu koncipovali velmi systematicky, veškerá data velmi komplexně zpracovávali, všechny výsledky $v$ manuálu detailně prezentují a současně interpretují, $k$ čemu a proč dospěli. S daty pracují velmi zodpovědně, přesně specifikují, za jakých okolností je vhodné diagnostický nástroj užít a kdy je naopak jeho administrace nevhodná. Rozhodně se domnívám, že je vhodné test dále šířit mezi odborníky v praxi. Oceňuji, že autoři uvažují i o variantě, že metodu budou administrovat proškolení učitelé, nejen psychologové či speciální pedagogové. Toto bezpochyby zajistí mnohem širší využití testu. Na druhou stranu v této souvislosti pokládám za důležité připravit skutečně velmi podrobné školení, na němž si potenciální uživatelé ze školní praxe osvojí postupy zpracování a interpretace výsledků. Metoda je po psychometrické stránce velmi důkladně zpracovaná, což se promítá i do výstupů získaných její administrací. Pro „nepsychology“ může být náročné se orientovat ve způsobu práce $s$ takovým typem informací, což by mohlo vést $k$ dezinterpretaci, či dokonce poškození probandů. Toto pokládám za nutné pečlivě ošetřit způsobem školení uživatelů testu.

\subsection{Závěry:}

Jedná se diagnostický nástroj s unikátním zaměřením. Doposud v České republice obdobná metoda nebyla $k$ dispozici. Je proto nanejvýš žádoucí, aby byl šířen a v maximální možné míře využíván v poradenské, školní i výzkumné praxi. 


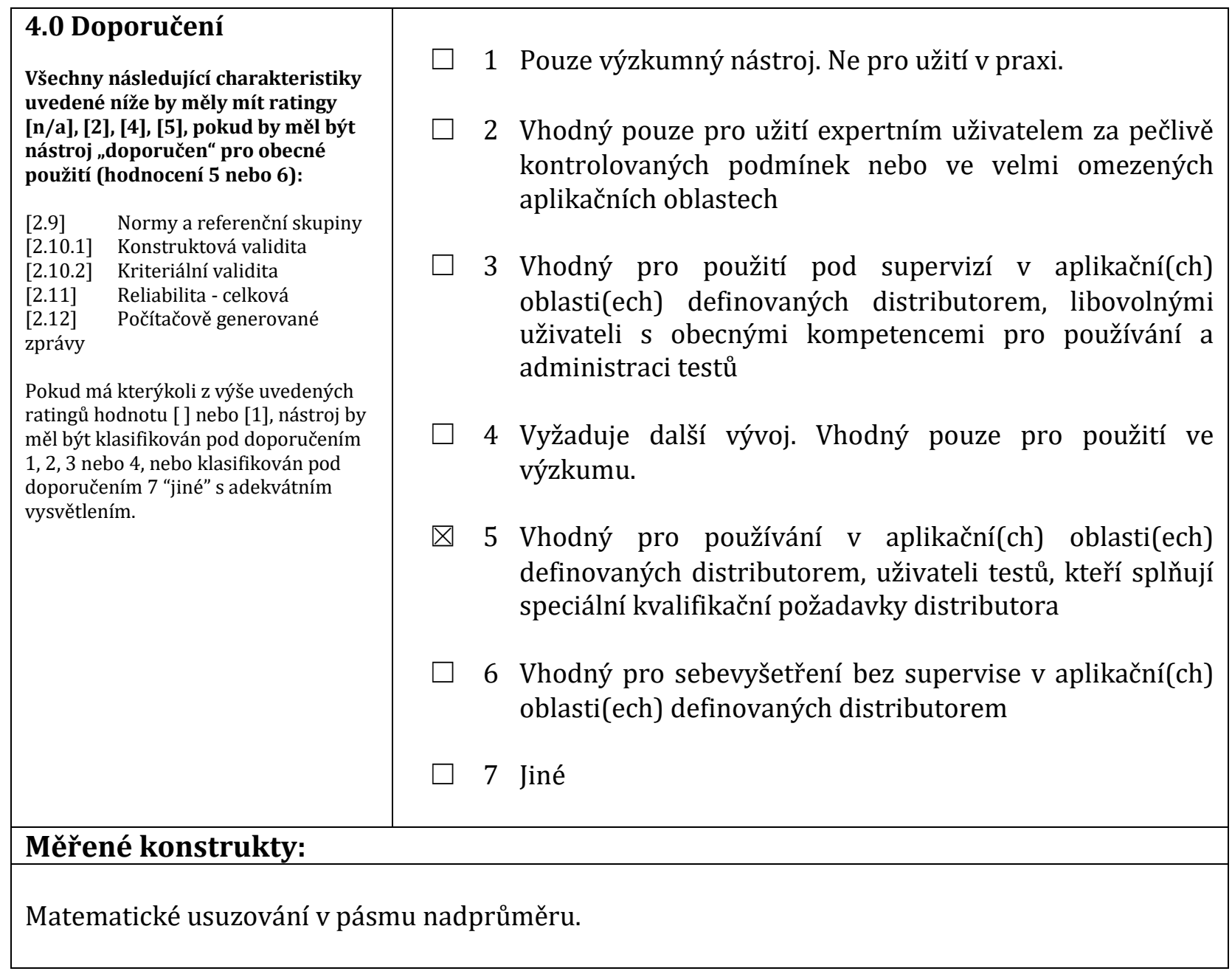

